\title{
Diabetes in the Bio-Breeding/Worcester Rat Induction and Acceleration by Spleen Cell-conditioned Media
}

Eugene S. Handler, John P. Mordes, Jonathan Seals, Steven Koevary, Arthur A. Like, Koji Nakano, and Aldo A. Rossini Departments of Medicine, Biochemistry, and Pathology, University of Massachusetts Medical School, Worcester, Massachusetts 01605

\begin{abstract}
Injections of media conditioned by concanavalin A-activated spleen cells from acutely diabetic rats accelerated the appearance of diabetes in young Bio-Breeding/Worcester (BB/W) rats. Activity was also found in media conditioned by spleen cells from nondiabetic, W-line Wistar Furth and Buffalo rats. Unconditioned media containing mitogen had no activity. Conditioned media also induced diabetes in resistant $\mathrm{W}$-line $\mathrm{BB} / \mathrm{W}$ rats but not in Wistar Furth rats. A soluble factor may activate a BB lymphocyte population that promotes diabetes.
\end{abstract}

\section{Introduction}

The Bio-Breeding (BB) ${ }^{1}$ rat develops autoimmune diabetes similar to Type I human diabetes mellitus $(1,2)$. The syndrome is characterized by sudden onset of hyperglycemia, ketonemia, and pancreatic beta cell destruction. Considerable evidence suggests that it has an autoimmune pathogenesis (1-3). Pancreatic lymphocytic insulitis is present; the disease can be prevented by immunosuppression and immune enhancement. Islet autoantibodies are also present.

It is also possible to transfer the disease to nondiabetic rats using splenic lymphocytes from acutely diabetic rats (4). The cells are cultured in the presence of concanavalin A (con A) and given intravenously to 30-35-d-old diabetes prone rats. Most rats become diabetic within 2 wk. Transfer to allogeneic histocompatible $\left(\mathrm{RT}^{\mathrm{u}}\right)$ and $\mathrm{RT} 1^{\mathrm{u}} \times$ non-RT1 ${ }^{\mathrm{u}} \mathrm{F}_{1}$ hybrid rats is also possible if recipients are immunosuppressed $(5,6)$, suggesting that the con A-activated cells constitute a cellular effector mechanism. The exact mechanisms by which spontaneous and induced BB rat diabetes occur remain unknown, and the present studies were undertaken to define the possible role of soluble factors in this process.

A preliminary account of this work has been presented in abstract form (Handler, E. S., J. P. Mordes, and A. A. Rossini. 1984. Induction of diabetes in the Bio-Breeding/Worcester [BB/W] rat with conditioned medium. Diabetologia. 27:284A). 1985 .

Received for publication 17 June 1985 and in revised form 17 July

1. Abbreviations used in this paper: ADSCM, acute diabetic spleen cellconditioned media; BB, Bio-Breeding; BB/W, Bio-Breeding/Worcester; BUF, Buffalo; con A, concanavalin A; WF, Wistar Furth.

J. Clin. Invest.

(c) The American Society for Clinical Investigation, Inc.

0021-9738/85/10/1692/03 $\$ 1.00$

Volume 76, October 1985, 1692-1694

\section{Methods}

Animals. Bio-Breeding/Worcester (BB/W) rats were obtained from the University of Massachusetts, Worcester (7). 40-60\% of these rats spontaneously become diabetic, most (>85\%) between 60 and $120 \mathrm{~d}$ of age. Fewer than $0.5 \%$ become diabetic before $60 \mathrm{~d}$ of age. We also used the diabetes-resistant $\mathrm{W}$-subline of $\mathrm{BB} / \mathrm{W}$ rats. Fewer than $1.5 \%$ of these rats develop diabetes. Unlike the diabetes-prone BB/W, they are neither lymphopenic nor immunodeficient. Wistar Furth (WF) and Buffalo (BUF) rats were obtained from Charles River Breeding Laboratories, Inc. (Wilmington, MA).

Rats were housed under standard conditions, fed ad lib., and weighed and tested twice weekly. Diabetes was diagnosed on the basis of glycosuria and a plasma glucose concentration $>200 \mathrm{mg} / \mathrm{dl}$. Equal numbers of male and female rats were used, and rat litters were randomly distributed into experimental and control groups.

Preparation of conditioned media. Activated spleen cells for adoptive transfer of diabetes were prepared as previously described $(4,6)$ and injected intravenously into 30-35-d-old diabetes-prone BB/W rats at a dose of $40 \times 10^{6}$ cells. Supernates from cell cultures were collected, pooled, and stored at $-30^{\circ} \mathrm{C}$. These acute diabetic spleen cell-conditioned media (ADSCM) were concentrated 10-fold using a 5-kD filter (YM5, Amicon Corp., Danvers, MA), passaged through a 0.45- $\mu \mathrm{m}$ filter (Nalge Co., Div. of Sybron Corp., Rochester, NY), and aliquots stored at $-10^{\circ} \mathrm{C}$. Some ADSCM was fractionated by molecular weight using Amicon filters YM5, 10, 30, and 50. For use as control injections, media without cells were incubated for $72 \mathrm{~h}$ either with or without con A and similarly concentrated 10-fold.

Histology and lymphocyte subset analysis. Pancreata were fixed in Bouin's solution. Sections were stained with hematoxylin and eosin and evaluated for insulitis by a pathologist (Dr. Like) who was unaware of the treatment status of the animals. Lymphocyte counts and subset were determined using a fluorescence activated cell sorter as previously described (8).

\section{Results}

Table I shows the result of administering ADSCM or activated cells to young diabetes-prone BB/W rats. Diabetes occurred before $60 \mathrm{~d}$ of age in rats given either activated cells or ADSCM. In contrast, diabetes did not occur before $60 \mathrm{~d}$ of age in any uninjected rats, rats treated with media alone, or rats treated with media containing con A. Diabetes occurred 21-28 (mean $=25) \mathrm{d}$ after the first injection of ADSCM compared with 1424 (mean $=17) \mathrm{d}$ after the injection of cells $(P<0.01$, MannWhitney $U$ test). Cells destroyed by sonication failed to produce diabetes.

Table I also shows the effect of fractionating ADSCM. Only rats given the highest molecular weight $(>50 \mathrm{kD})$ material became diabetic, and they did so much earlier than rats in other groups. The final percentage of rats developing diabetes by 130 d was not, however, affected by ADSCM treatment.

Histologically, the pancreata of all diabetic ADSCM-treated 
Table I. Frequency and Age at Onset of Diabetes in Diabetes-prone BB/W Rats Given Activated Spleen Cell-conditioned Media or Activated Spleen Cells

\begin{tabular}{|c|c|c|c|c|c|}
\hline & $\begin{array}{l}\text { No. } \\
\text { tested }\end{array}$ & $\begin{array}{l}\text { No. diabetic } \\
\text { at } 60 \mathrm{~d}\end{array}$ & $\begin{array}{l}\text { No. diabetic } \\
\text { at } 130 \mathrm{~d}\end{array}$ & $\begin{array}{l}\text { Mean age } \\
\text { at onset }\end{array}$ & Range \\
\hline \multicolumn{6}{|l|}{ ADSCM Recipients* } \\
\hline Complete ADSCM & 16 & $4 \ddagger(25 \%)$ & $6(38 \%)$ & $57^{\prime \prime}$ & $51-65$ \\
\hline Media $+\operatorname{con} \mathrm{A}$ & 15 & $0(0 \%)$ & - & - & - \\
\hline Media alone & 8 & $0(0 \%)$ & - & - & - \\
\hline \multicolumn{6}{|l|}{ ADSCM fractions } \\
\hline $5-10 \mathrm{Kd}$ & 7 & $0 \quad(0 \%)$ & $6(86 \%)$ & 97 & $87-122$ \\
\hline $10-30 \mathrm{Kd}$ & 8 & $0(0 \%)$ & $2(25 \%)$ & 93 & $92-95$ \\
\hline $30-50 \mathrm{Kd}$ & 8 & $0 \quad(0 \%)$ & $3(38 \%)$ & 90 & $82-104$ \\
\hline$>50 \mathrm{Kd}$ & 6 & $5 \ddagger(83 \%)$ & $6(100 \%)$ & $55^{\prime \prime}$ & $50-61$ \\
\hline No injection & 17 & $0(0 \%)$ & $13(76 \%)$ & 106 & $74-114$ \\
\hline \multicolumn{6}{|l|}{ Cell Recipients§ } \\
\hline Con A cells & 7 & $4(57 \%)$ & - & - & - \\
\hline Sonicated cells & 8 & $0 \quad(0 \%)$ & - & - & - \\
\hline No injection & 8 & $0 \quad(0 \%)$ & - & - & - \\
\hline
\end{tabular}

Treatment of recipients was begun at 30-35 d of age. ADSCM $(1 \mathrm{ml})$ was injected intraperitoneally five times per week for 4 wk. Rats given cells received $40 \times 10^{6}$ cells/rat or the same number of cells after disruption in a sonicator. Comparisons are based on the chi ${ }^{2}$ statistic.

* Overall $P<0.001$. $\ddagger P<0.05$ vs. controls. $\S$ Overall $P<0.05$. " $P<0.001$ vs. other groups.

rats showed insulitis, end stage islets, severe pancreatitis, and peritonitis. Similar studies in rats given unconditioned media with or without con $A$ and sacrificed at $60 \mathrm{~d}$ of age revealed mild peritonitis and pancreatitis but no insulitis.

ADSCM treatment of nine diabetes-resistant $\mathrm{W}$-line rats produced three diabetics (33\%) within 3 wk of the first injection. Mean age at onset of diabetes was $51 \mathrm{~d}$. The three diabetic Wline rats were not lymphopenic. Their peripheral white blood cell counts and differentials determined on tail vein blood averaged $12,367 / \mathrm{mm}^{3}$ with $80 \%$ mononuclear cells (principally lymphocytes), $17 \%$ polymorphonuclear cells, and $3 \%$ eosinophils. These values are similar to those of untreated W-line rats ( $n$ =6) which averaged $13,000 / \mathrm{mm}^{3}, 88 \%$ mononuclear cells, $10 \%$ polymorphonuclear cells, and $1 \%$ eosinophils. Splenic lymphocyte subset analysis of one diabetic W-line rat showed $20 \% \mathrm{OX}^{+}$ suppressor/cytotoxic cells and $26 \% \mathrm{~W} 3 / 25^{+}$helper cells, percentages comparable to those previously reported for nondiabetic W-line rats (9).

Media conditioned by con A-activated spleen cells from RT $1^{\text {u }}$ $\mathrm{W}$-line, $\mathrm{RT} 1^{\mathrm{u}} \mathrm{WF}$, and $\mathrm{RT} 1^{\mathrm{b}} \mathrm{BUF}$ rats also accelerated the onset of diabetes in the $\mathrm{RT} 1^{\mathrm{u}}$ diabetes-prone $\mathrm{BB} / \mathrm{W}$ rat (Table II). The time course, age at onset, and characteristics of the diabetic syndrome were similar to those observed with ADSCM injections. Table II also shows that injections of con A-activated spleen cells from nondiabetic major histocompatibility complex compatible or -incompatible spleen cells do not induce or accelerate diabetes.

We also tested ADSCM in intact $(n=15)$ and cyclophosphamide-treated $(150 \mathrm{mg} / \mathrm{kg}, n=4)$ immunosuppressed WF rats. None became diabetic. In addition, the administration of activated WF spleen cell-conditioned media to intact $(n=8)$ or cyclophosphamide immunosuppressed $(n=10)$ WF recipients failed to induce diabetes. Histologically, all had evidence of mild pancreatitis and peritonitis but none had insulitis.

\section{Discussion}

These experiments suggest that a soluble factor in ADSCM accelerates diabetes in diabetes-prone $\mathrm{BB} / \mathrm{W}$ rats and transfers it to resistant $\mathrm{W}$-line rats. The lack of diabetogenicity in sonicated and irradiated (10) con A-treated cells suggests that there is little intracellular storage of the factor. The induction of diabetes in W-line rats suggests that lymphopenia may not be essential for the expression of diabetes as previously proposed (11). An inactive effector cell population may be present in $\mathrm{W}$-line rats.

It is interesting to note that transfusions of certain cells protect against diabetes, (12) while a soluble factor obtained from the same cells can induce and accelerate the onset of the disease. One may speculate that viable transfused lymphocytes specifically enhance suppressor cell activity, perhaps by establishing a chimera. In contrast, a nonspecific factor may directly activate an effector cell specific to the BB rat, or, alternatively, reduce suppressor cell activity. Since control media, with and without con $\mathrm{A}$, that were concentrated to the same extent as ADSCM failed to produce diabetes, it is unlikely that the active soluble factor is a nutrient constituent of media or of con A itself. In

Table II. Frequency of Diabetes Before $60 \mathrm{~d}$ of Age in Diabetes-prone BB/W Rats Given Spleen Cell-conditioned Media or Activated Spleen Cells from Various Donor Rats

\begin{tabular}{|c|c|c|c|c|c|c|}
\hline & \multicolumn{6}{|c|}{ Lymphocyte donor strain and haplotype } \\
\hline & \multicolumn{2}{|c|}{ W-line ( $\left.R T 1^{u}\right)$} & \multicolumn{2}{|c|}{$\mathrm{WF}\left(\mathrm{RT} 1^{\mathrm{a}}\right)$} & \multicolumn{2}{|c|}{ BUF $\left(R T 1^{b}\right)$} \\
\hline & Media & Control & Media & Control & Media & Control \\
\hline Number tested & $7^{*}$ & 9 & $14^{*}$ & 13 & $8 \dagger$ & 8 \\
\hline \multirow[t]{2}{*}{ Diabetic } & 6 & 0 & 7 & 0 & 5 & 0 \\
\hline & Cells & Control & Cells & Control & Cells & Control \\
\hline Number tested & 6 & 6 & 8 & 8 & 8 & 8 \\
\hline Diabetic & 0 & 0 & 0 & 0 & 0 & 0 \\
\hline
\end{tabular}

Spleen cell-conditioned media were prepared and concentrated 10 -fold as outlined in Table I except that donors were nondiabetic W-line, BUF, and WF rats. Recipients were 30-35-d-old, diabetes-prone $\mathrm{BB} / \mathrm{W}$ rats. Control rats in these experiments received no injections.

* $P<0.005$ vs. control.

$\dagger P<0.05$ vs. control. 
addition, accelerating activity was seen in ADSCM from which the mitogen had been removed using adsorbent (agarose- $p$-aminophenyl- $a$-D-mannopyranoside; P-L Biochemicals, Inc., Milwaukee, WI).

The mechanism of action of ADSCM is not clear. Mitogenactivated spleen cells release many products, some of which are associated with lymphocyte growth and differentiation. Preliminary studies in our laboratory indicate that while interleukin2 is present in ADSCM, injections of synthetic interleukin-2 do not affect the onset of diabetes in BB/W recipients (unpublished observations). It has been suggested that Ia antigens may be expressed on BB rat beta cells (13); if so, it could be that ADSCM induces such antigens. We have found, however, that ADSCM does not induce Ia antigens on rat insulinoma cells or rat macrophages (unpublished observations). The nature of the diabetogenic factor(s) produced by con A-activated spleen cells and their target cell populations in the $\mathrm{BB} / \mathrm{W}$ rat remain to be determined.

\section{Acknowledgments}

We thank Anne Pelletier, Olita Treimanis, Glenn Rouleau, Loretta Lee, and Barbara Papazian for their help. We also thank Drs. Dale Greiner, Gary Johnson, and David Parker for reading the manuscript.

This work was supported by grants AM 25306 and AM 19155, and contract AM 4-2254 from the National Institutes of Health.

\section{References}

1. Like, A. A., L. Butler, R. M. Williams, M. C. Appel, E. J. Weringer, and A. A. Rossini. 1982. Spontaneous autoimmune diabetes mellitus in the BB rat. Diabetes. 31(Suppl. 1):7-13.

2. Yale, J.-F., and E. B. Marliss. 1984. Altered immunity and diabetes in the BB rat. Clin. Exp. Immunol. 57:1-11.

3. Rossini, A. A., J. P. Mordes, and A. A. Like. 1985. Immunology of insulin-dependent diabetes mellitus. Annu. Rev. Immunol. 3:291-322.
4. Koevary, S., A. A. Rossini, W. Stoller, W. Chick, and R. M. Williams. 1983. Passive transfer of diabetes in the BB/W rat. Science (Wash. DC). 220:727-728.

5. Koevary, S., R. M. Williams, W. Stoller, and W. L. Chick. 1983. Passive transfer of diabetes in $\mathrm{BB} / \mathrm{W}$ and Wistar Furth rats. Diabetes. 32:200A. (Abstr.)

6. Like, A. A., E. J. Weringer, A. Holdash, P. McGill, D. Atkinson, and A. A. Rossini. 1985. Adoptive transfer of autoimmune diabetes mellitus in BioBreeding/Worcester (BB/W) inbred and hybrid rats. J. Immunol. 134:1583-1587.

7. Like, A. A., and A. A. Rossini. 1984. Spontaneous autoimmune diabetes mellitus in the BioBreeding/Worcester rat. Surv. Synth. Pathol. Res. 3:131-138.

8. Gilman, S. C., B. A. Woda, and J. D. Feldman. 1981. T lymphocytes of young and aged rats. I. Distribution, density and capping of $T$ antigens. J. Immunol. 127:149-153.

9. Rossini, A. A., S. Slavin, B. A. Woda, M. Geisberg, A. A. Like, and J. P. Mordes. 1984. Total lymphoid irradiation prevents diabetes mellitus in the Bio-Breeding/Worcester (BB/W) rat. Diabetes. 33:543547.

10. Mordes, J. P., K. Nakano, D. L. Gallina, A. A. Like, and A. A. Rossini. 1984. Irradiation of activated lymphocytes from BB rats prevents adoptive transfer of diabetes but does not vaccinate against spontaneous diabetes. Clin. Res. 32:404A. (Abstr.)

11. Jackson, R. A., J. B. Buse, R. Rifai, D. Pelletier, E. L. Milford, C. B. Carpenter, G. S. Eisenbarth, and R. M. Williams. 1984. Two genes required for diabetes in BB rats. Evidence from cyclical intercrosses and backcrosses. J. Exp. Med. 159:1629-1636.

12. Rossini, A. A., D. Faustman, B. A. Woda, A. A. Like, I. Szymanski, and J. P. Mordes. 1984. Lymphocyte transfusions prevent diabetes in the Bio-Breeding/Worcester rat. J. Clin. Invest. 74:39-46.

13. Dean, B. M., R. Walker, A. J. Bone, A. Cooke, G. F. Bottazzo, and J. D. Baird. 1984. Development of diabetes in the BB/E rat (II). Expression of class II molecules (Ia) in islet cells. Diabetologia. 27:269A. (Abstr.) 